\title{
BOŞANMA VE AYRILIĞA UYGULANACAK HUKUK KONUSUNDAKİ AVRUPA KONSEYİ ROMA III TÜZÜĞÜ KAPSAMINDA HUKUK SEÇIMI*
}

\section{H. Akif KARACA**}

\section{$\ddot{\boldsymbol{O}} z$}

Aile hukukunda gözlemlenen statüden sözleşmeye doğru evrim irade serbestîsi ilkesinin belirli sinırlamalarla aile hukukunda da yaygınlaşması etkisini doğurmuştur. Statü anlaylşı kapsamında da taraflar irade serbestîsine sahip olmakla beraber bu serbesti aile hukuku içindeki maddi nitelikli ilişkilerle sinırllydl. Statüden sözleşmeye doğru evrimle sadece maddi nitelikli ilişkiler değil, diğer hak ve yükümlülükler ve boşanmanın sebepleri dahi taraflarca kararlaştırllabilmektedir. Bazl hukuk sistemlerinde kusura dayalı olmayan boşanma anlayışı gelişmiş ve boşanma tarafların talebi ile mümkün hale gelmiştir. Maddi hukuktaki bu gelişmelerin kanunlar ihtilafi hukuku alanındaki etkisi maddi nitelikli ilişkiler haricinde de hukuk seçimi imkânının tanınması olmuştur. Boşanma ve Ayrllı̆̆a Uygulanacak Hukuk Konusundaki Roma III Tüzüğ̈̈'nde taraflara kendileriyle mutad mesken veya vatandaşlık gibi belirli irtibatlara sahip hukuk sistemlerini veya lex foriyi uygulanacak hukuk olarak seçme imkânının tanınması bu gelişmeler neticesi gerçekleşmiştir. Hukuk seçimi imkânının tanınması milletlerarası özel hukukun diğer alanlarında olduğu gibi aile hukuku ilişkilerinde de öngörülebilirliği ve hukuk güvenliğini artırıcı niteliktedir. Ayrıca, forum-shopping yoluyla dolayl hukuk seçimini de engelleyecektir. Hukuk seçimi imkânının tanınmasının bir diğer etkisi de şahsi statünün bağlama noktaları olan vatandaşlık, ikametgâh ve mutad meskene dair teorik tartışma ve gerekçelendirmelerin etkisizleşmesidir. Makalemizde aile hukukunun evrimi ve bu evrim üzerine inşa edilen kanunlar ihtilafi hukuku alanındaki gelişmeler kapsamında Roma III Tüzüğ̈̈’nde sağlanan hukuk seçimi imkânı ayrıntılı bir şekilde incelenmektedir.

Anahtar Kelimeler: Aile hukuku, sözleşmeselleşme, irade serbestîsi, boşanma, hukuk seçimi.

* Makalenin maddi hukuk boyutunun yazımı sırasında görüşleriyle katkıda bulunan Prof. Dr. Burak Özen'e teşekkürlerimi sunarım.

** Dr. Öğr. Üyesi, Marmara Üniversitesi Hukuk Fakültesi, Milletlerarası Özel Hukuk Anabilim Dalı, e-posta: akif.karaca@marmara.edu.tr. 


\section{CHOICE OF LAW IN THE CONTEXT OF EUROPEAN COUNCIL ROME III REGULATION ON THE LAW APPLICABLE TO DIVORCE AND LEGAL SEPERATION}

\section{Abstract}

The evolution observed in family law from status to contract resulted in expansion of party autonomy principle in family law with some limitations. Although, parties also have party autonomy under the status understanding, it is limited to pecuniary relations in family law. With the evolution from status to contract, parties can determine not only rights and obligations relating to pecuniary relations but also to other fields of family law. Parties can even determine causes of divorce. In some legal systems non-fault divorce concept has developed. Under this concept divorce can occur based on demand of a party. The effect of these developments in substantial law is providing choice of law in conflict of laws issues in the field of family law. The right of the parties to choose a legal system that has a connection to them based on nationality or habitual residence or to choose lex fori for their divorce cases under Rome III Regulation on the Law Applicable to Divorce and Legal Seperation is recognised based on these developments. Choice of law enhances predictibility and legal security in the field of family law matters as in the other fields of conflict of laws. Moreover, it will prevent indirect choice of law through forum shopping. The theorotical discussions and justifications relating to use of connecting factors of personal status that are nationality, domicile and habitual residence become ineffective after recognition of choice of law. In this article, the evolution of family law and the development of conflict of laws relating to family law and divorce matters based on that evolution and the choice of law provided by Rome III Regulation in this context is analysed in detail.

Keywords: : Family law, contractualisation, party autonomy, divorce, choice of law.

\section{Giriş}

Gerek Dünya genelinde sosyal hareketliliğin artması gerekse Avrupa Birliği (AB) bünyesinde sınırların kalkması ve kişilerin serbest dolaşımı yabancı unsurlu evlenmelerde ve bu durumun doğal sonuçlarından biri olan boşanmalarda büyük artış meydana getirmiştir. (Gaertner, 2006: 99; Fiorini, 2008: 179) Aile kurumuna dönük yaklaşımın daha liberal hale gelmesi de boşanmalardaki artışa katkı sağlamaktadır. Yabancı unsurlu evlenme ve boşanmalardaki bu artış uygulanacak hukuk problemini de kendiliğinden ortaya çıkarmaktadır. (Fiorini, 2008: 179) Boşanmak isteyen fertler doğal olarak boşanmayı kolay elde edebilecekleri hukuklara yönelmektedir. Bu forum seçme 
yoluyla olabileceği gibi, Roma III Tüzüğü kapsamında aşağıda ayrıntılı inceleyeceğimiz üzere hukuk seçimi yoluyla da mümkün olabilmektedir.

$\mathrm{AB}$ üyesi ülkelerde her ne kadar boşanmayı yasaklayan bir hukuk sistemi en son 2011 y1lında Malta'daki boşanma yasağının kalkmasıyla kalmamışsa da boşanma sebepleri noktasında ciddi maddi hukuk farklılıkları mevcuttur. Finlandiya, İsveç gibi kuzey ülkelerinde aile kurumuna yaklaşımın son derece liberal olduğu ve kusura dayalı boşanma sebebine ihtiyaç olmadığ İrlanda vb. katolik kültüre sahip ülkelerde tam zıddı bir anlayış geçerlidir. Boşanmanın elde edilme hızı da ülkeden ülkeye değişmektedir. (Gaertner, 2006: 114) $\mathrm{AB}$ üyesi ülkelerde boşanmaya ilişkin maddi hukuk düzenlemelerinde farklılıklar olduğu gibi kanunlar ihtilafı kuralları da $\mathrm{AB}$ üyesi ülkelerde birbirinden farklılık göstermekteydi. Bir yanda sadece lex fori'nin uygulanmasını öngören İngiliz hukuku bulunurken öte yanda sıkı ilişkili hukuku bulmaya dönük farklı öncelik sıralarıyla milli hukuk, ikametgâh ve sosyal hareketliliğin artmasıyla kullanılmaya başlanan mutad mesken gibi diğer bağlama noktalarını kullanan Kıta Avrupası ülkeleri hukukları bulunmaktadır. (Fiorini, 2008: 179)

Herhangi bir boşanmada temel olarak üç mesele ile karşılaşılmaktadır. Bunlardan birincisi hukuki statüde değişikliğe sebep olan boşanma kararının verilmesi, ikincisi boşanma sonucu mal rejiminin tasfiyesi, üçüncüsü ise nafaka ve tazminat meselesidir. (Harding, 2011: 204) Bizim makalemizin konusu bunlardan birincisine uygulanacak hukuku konu edinen Roma III Tüzüğü kapsamında hukuk seçimidir. Diğerleri farklı tüzüklerin konusunu oluşturmaktadır.

Aile hukuku gibi toplumun kültürel değerlerinin esaslı rol oynadığı hukuk disiplinlerinde maddi hukuk boyutunda uyumlulaş̧ırmanın mümkün olmaması nedeniyle, maddi hukuk farklılklarını koordine edecek olan kanunlar ihtilafı kurallarının uyumlulaştırılması yoluna gidilmiştir. (Fiorini, 2008: 192) AB ülkelerinde boşanmaya uygulanacak hukukun tespitinde kanunlar ihtilafı alanında bir uyumlulaştırma çalışması olan Roma III Tüzüğü son derece yenilikçi bir yaklaşımla hukuk seçimini mümkün hale getirmiştir. Hukuk seçimi milletlerarası özel hukukta geleneksel olarak sözleşmeler alanında kabul edilmiş bir prensiptir. Sözleşmelerdeki hukuk seçimi küreselleşen uluslararası ticaretin gerektirdiği pragmatizme ve kamu düzeni ve zayıf tarafin korunması şartıyla bir insanın kendi kişsisel ve ekonomik yaşamını kendisinin düzenleyebilmesine dayanan insan hakları anlayışına dayanmaktadır. $\mathrm{Bu}$ gerekçelerin pekâlâ aile hukuku ilişkilerinde de hukuk seçimine dayanak olarak gösterilebileceği ileri sürülmüştür. (Carruthers, 2012: 882) 
Bununla birlikte dikkate alınması gereken önemli husus aile hukuku ilişkileri ile sözleşmenin farklılı̆̆ıdır. Aile kurumu hukuken sözleşmeden ziyade bir statü meselesi olarak ele alınmaktadır. Bunun doğal sonucu ise tarafların içeriğini iradeleri ile belirleyemeyecekleri, aksine içeriği önceden belirlenmiş bir statüye dâhil olmalarıdır. (Carruthers, 2012: 883) Öte yandan, aile kurumunun kamu düzenini ilgilendiren ve kamusal yönü ağır basan bir özel hukuk kurumu olduğuna dönük anlayış da bu konuda irade serbestîsinin olup olmayacağı bakımından önemlidir. (Shakargy, 2013: 501) Kamu düzeninin ve güveninin korunması, zayıf durumda olan kadın ve çocuğun korunması ve buna dönük yasal düzenlemeler aile hukukunda yer alsa da nihayetinde eşit bireyler arasında özerk iradelerle kurulması onun özel hukuk dalı vasfinı ortaya koyar. (Serozan, Başoğlu, Kapanc1, 2016: 533) Bu nedenlerle kanunlar ihtilafi kurallarının nihayetinde maddi hukukun aile hukuku anlayışından etkilendiğini dikkate alarak temel konumuz olan boşanmada hukuk seçimi meselesini incelemeden önce aile kurumunun maddi hukuktaki evriminin öncelikle incelenmesi gerekmektedir.

\section{Aile Kurumunun Hukuki Evrimi: Statüden Sözleşmeye}

Sosyal boyutları bulunan bir özel ilişki olan evlilik ilk dönemlerden itibaren dinlerin düzenleme alanına girmiştir. Avrupa'da kilise hukuku, Ortadoğu'da ise İslam hukuku tarafindan düzenlenmiştir. Ulus devletlerin ortaya çıkması ile beraber kodifikasyon hareketleri laik nitelikli olsa da evlenme ehliyeti ve yasakları, boşanma sebepleri gibi bir çok alanda dini düzenlemeler kodifikasyon hareketlerini de etkilemişlerdir. (Shakargy, 2013: 506) Medeni hukuk bir şahsın ait olduğu kültür çevresinin de etkisini taşımaktadır. (Yetano, 2010: 189) $\mathrm{Bu}$ nedenle, bu doğal bir sonuçtur. Her ne kadar, 1861 tarihinde Maine aile ilişkilerinde artan bireyciliğin aile kurumunun statüden sözleşmeye doğru evrilebileceğinin işareti olduğuna dikkat çekmişse de II. Dünya Savaşı sonuna kadar olan dönemde evlilik Avrupa hukuklarında dahi hukuken bir statü meselesi olarak ele alınmıştır. Kişiler evlenmekle şartları önceden hukuk düzeni tarafından ayrıntılı bir şekilde düzenlenmiş bir hukuki statüye dâhil olmaktadırlar. (Shakargy, 2013: 509) Taraflar bu statülerin içeriğini kendileri düzenleyemezler. (Kapanc1, 2015: 97)

Gerek eşler gerek anne baba ile çocuk arasındaki aile hukuku ilişkileri sınırlı sayı ilkesine bağlı belirli statüler çerçevesinde belirlenmektedir. Statüye bağlılık ilkesi sonucu nişanlanma, evlenme, soybağ1 ilişkilerinin içeriği kişilerce tasarruf edilemez şekilde belirlenmiştir. Sosyal güvenlik, vergi, ceza hukuku gibi alanlarda bu statülere sonuç bağlanmaktadır. Bu statülere giriş, statüden çıkış ve statülerin içerikleri emredici kurallarla düzenlenmiştir. Bu düzenlemenin temelinde yatan sebep ailenin toplumun en küçük birimi olarak kabul edilmesidir. (Serozan, Başoğlu, Kapanc1, 2016: 550) Türk hukukunda bizatihi Anayasa m. 41'de yer aldıği üzere aile toplumun temeli, çekirdeği 
olarak kabul edilmiştir. Bu kabulün sonucu aile hukukunun özel hukuk ile kamu hukukunun kesiştiği bir alan olarak özel hukukun kendine özgü bir alanı olarak ortaya çıkmasıdır. (Kapanc1, 2015: 98)

Aile hukuku ilişkilerinin birer statü olarak belirlenmesinin sonucu özel hukukun diğer alanlarının aksine irade özgürlüğüne yer verilmemesidir. " $B u$ hukuk dalında statü olarak tanımlanan hukuki yapılar, diğer sözleşmesel yapılardan farklılık gösterir. Belirleyici olan aile hukuku kurallarının emredici özellikleridir. Temel bir ilke olarak, bu kurallardan sapılabilmesi olanaklı değildir. Bir defa var olan aile hukuku statülerinin kurulması ve içerikleri bu şekilde önceden saptanmıştır. Bu ilişkilerin içeriklerinin taraflarca farklı şekilde düzenlenmesi de kabul edilemez, söz gelimi evlilik öncesi anlaşmalar eşlerin içine girecekleri statülerin hak ve borçlarını kanunun öngördüğ̈̈ düzenden farklı tasarladıkları ölçüde geçersiz sayılır." (Serozan, Başoğlu, Kapanc1, 2016: 551)

Bununla beraber belirtmek gerekir ki Türk hukuku gibi aile hukukunu statüler alanı olarak kabul eden hukuk sistemlerinde dahi son derece sinırlı olarak olsa da sözleşme serbestîsi vardır. Eşler maddi yükümlülükler haricindeki evlilik içi yükümlülükler için sözleşme yapamasalar da maddi yükümlülükler konusunda sözleşme yapabilirler. Evlilik hukuki kişiliği bulunmayan, hukuki boyutunun yanı sıra ekonomik boyutu olan bir ortaklıktır. Eşler evlilik içi masraflara dair anlaşma yapabilirler. Bu anlaşmalar tarafların iradesi ile ileride değiştirilebilir. Tek taraflı değişiklik için anlaşmanın oluştuğu ekonomik şartlarda esaslı değişiklik olması gerekir. (Kapancı, 2015: 104-105) $\mathrm{Bu}$ açıklamalardan anlaşılacağı üzere statüler rejimini kabul eden hukuklarda taraflar sadece üzerinde tasarruf edebilecekleri konularda anlaşma yapabilmektedirler. (Kapanc1, 2015: 109)

İrade serbestîsi tanınan bir diğer alan ise şartlarının oluşması ve hâkim tarafindan da onaylanması koşuluyla anlaşmalı boşanma sebebine dayalı boşanma halinde boşanma sonrası nafaka yükümlülükleri ve malların tasfiyesi konusunda taraflar anlaşabilmektedir. (Serozan, Başoğlu, Kapancı, 2016: 555) Bununla birlikte, anlaşmalı boşanma halinde dahi taraflar boşanmanın maddi sonuçları haricindeki diğer sonuçlarına dönük anlaşma yapamamaktadırlar. Anlaşmalı boşanma Türk hukukunda Medeni Kanun (MK) m. 166'da düzenlenen sınırlarla, mahkeme tarafindan onaylanma ile mümkün olur. Belirtilmesi gereken husus boşanmanın içeriği taraflarca değil MK kuralları tarafindan düzenlenmektedir. (Kapanc1, 2015: 105)

Evliliğin kültürel ve kamu düzenini ilgilendiren sosyal boyutunun sonucu olarak devletler bir kişinin evlenebilip evlenemeyeceğinden kimle evlenebileceğine, evlenme şekline, evlilik içindeki hak ve yükümlülük dengesine, boşanabilip boşanamayacağına, boşanabilecekse hangi sebep ve 
koşullarda boşanabileceğine ve boşanma sonrası yükümlülüklere kadar gayet ayrıntılı bir şekilde düzenlemişlerdir. Devletler evliliğin hukuken istikrar arz eden ve ayrıntılı düzenlenmiş bir alan olmasına özen göstermişlerdir. (Shakargy, 2013: 509) Devletlerin evlenme ve boşanma meselelerini bu denli ayrıntılı düzenlemesi devletlerin vatandaşlarının evliliklerine verdikleri özel önemin, aile kurumunun sosyal düzen ve kamu düzeni bakımından taşıdığ önemin de göstergesidir. Maddi hukuk alanındaki ayrıntılı düzenleme ve bu düzenlemelerin nitelikleri aşağıda ayrıntılı ele alacağımız üzere kanunlar ihtilafı hukuku alanına da yansımış ve bütünüyle kişisel hukuka tabi tutulmuştur. Vatandaşları başka ülkelere gitseler dahi devletin özel ilgisinin sonucu olarak kendi ülkeleriyle vatandaşlık veya ikametgâh gibi yeterli bağlantıları korudukları sürece aile hukuku ilişkilerine kendi hukuklarını uygulama yoluna gitmişlerdir. (Shakargy, 2013: 509-510)

Aile hukukunda sözleşme serbestîsinin getirilmesi, bir başka ifadeyle aile hukukunun sözleşmeselleştirilmesi ailenin devlet yerine aile ve bireyler tarafından hukuki açıdan bağlayıcı işlemlerle düzenlenmesi demektir. (Swennen, 2013) Statüden sözleşmeye doğru evrimin temelinde toplumsal yapının en küçük biriminin aileden ziyade birey olduğu düşüncesi bulunmaktadır. Aile hukukunun merkezinde bireyin yer almasıyla bireyin menfaatleri ön plana çıkmaktadır. Sınırlı sayılı statü anlayışının terk edilmesiyle aile hukuku ilişkilerinin kurulması ve sona erdirilmesi sözleşmesel temellere dayandırılabilmekte ve kolaylaşmaktadır. (Serozan, Başoğlu, Kapancı, 2016: 550) Kadının özgürleşmesi ve evlilik ilişsisi içerisinde eşit birey olarak kabul edilmesi de ailenin kavramsal olarak erkek tarafından yönetilen bir birliktelikten ziyade artık bir bireyler topluluğu olarak tanımlanmasına yol açmıştır. (Shakargy, 2013: 513)

II. Dünya Savaşı sonrası dönemde liberalleşme ile birlikte aile hukuku alanında dini ve politik düzenlemelerin ve devletin müdahalesinin etkisi giderek zayıflamıştır. Aile birlikteliğinin kurulması ve sona erdirilmesi devlet organlarının katılımıyla mümkün olsa da aile içi ilişkilerin düzenlenmesinde bu etki zayıflamış ve büyük oranda taraflara bırakılmıştır. (Shakargy, 2013: 510) Aynı zamanda evlenme engelleri olan yaş, akrabalık, bekleme süreleri, evlenmenin şekli gibi alanlarda daha liberal düzenlemelere yer verilmiştir. (Shakargy, 2013: 510-511) Evlenme alanındaki bu tercihler boşanma alanına ve özellikle boşanma sebeplerine de yansımıştır. Bunun en önemli görünümü özellikle kuzey ülkelerinde kusura dayanmayan boşanmanın ortaya çıkmasıdır. Kusura dayalı boşanma tarafların boşanma hakkını belirli şartlar oluşmadıkça reddederken, kusura dayanmayan boşanma boşanmayı bir hak olarak taraflara tanımaktadır. Kusura dayanmayan boşanmada boşanmanın gerçekleşip gerçekleşmeyeceği değil hangi koşullarla gerçekleşeceği mesele edilmektedir. (Shakargy, 2013: 512) 
Boşanmada hukuk seçimine imkân verilmesinin temelinde yatan sebeplerden biri de kanaatimizce kusura dayalı olmayan boşanma olgusunun ortaya çıkmasıdır. Hukuk seçimi imkânı tanınmasının temelinde boşanmayı kolaylaştıran hukukların tercih edilmesi yatmaktadır. Kanunlar ihtilafı alanında hukuk seçimi imkânının tanınması tarafların kendileri için en avantajı hukuku seçmelerini sağlar. Aile hukuku alanında ise bu en az kısıtlama getiren hukuk olacaktır. (Yetano, 2010: 179) Ayrıca belirtmek gerekir ki, hukuk seçimi imkânı ile taraflara objektif kanunlar ihtilafı kurallarına göre uygulanacak hukuktan başka hukukun uygulanmasının sağlanması kısıtlamaları sistematik olarak etkisiz hale getireceği için kanunlar ihtilafi alanındaki bu anlayış değişikliği daha liberal bir aile hukukunun ortaya çıkmasına sebep olabilecektir. (Yetano, 2010: 179)

Evlilik kurumu devletler tarafindan aktif bir şekilde düzenlenen ve kontrol edilen bir kurumdan ekonomik sosyal vb. yükümlülüklerin taraflarca düzenlendiği, evliliğin kurulması ve sona erdirilmesinin kurallarının daha basite indirgendiği, gittikçe tarafların tercihlerine önem veren daha esnek bir kurum haline gelmiştir. Bu yönüyle koşulları önceden belirlenmiş bir statüye dâhil olmaktan öte içeriği büyük oranda taraflarca belirlenen bir sözleşme tarzına evrilmiştir. (Shakargy, 2013: 515) Aile hukuku alanında devletin düzenlemesi devam etmekte ancak bu daha ziyade, sözleşmeler alanındaki gibi, yedek kurallar koyma ve uyuşmazlıkları çözme yoluyla olmaktadır. (Shakargy, 2013: 516) Devlet evliliğin kuruluşuna ilişkin süreç ve sona ermesine ilişkin yargısal düzenlemeler ve içeriğe ilişkin yedek kuralların yanı sıra zayıf çocukların ve kadınların korunması vb. alanlarda emredici nitelikte kurallar koymaktadır. (Serozan, Başoğlu, Kapancı, 2016: 533-534) Bu yönüyle modern evlilik kurumunda devletler evliliğin içeriği ile ilgilenmemektedir. Evlilik devlet tarafindan düzenlenen, yönetilen bir kurum olmaktan ziyade devlet tarafindan fonksiyonelliği kolaylaştırılan bir kurum haline gelmiştir. (Shakargy, 2013: 515)

Batı hukuklarında artık evlilik sözleşmesel bir ilişki olarak kabul edilmeye başlanmıştır. İrade serbestîsi ve liberalleşmenin artmasıyla taraflar maddi yükümlülüklerin yanı sıra aile içi iş bölümü, evlilik içi yükümlülükler ve hatta Amerikan hukukunda anlaşmalı evliliklerde olduğu gibi evliliği sona erdirmenin şartlarını dahi düzenleyebilmektedir. Bu yönüyle evlilik kutsal bir birliktelikten sözleşmeye dönüşmüştür. (Shakargy, 2013: 527) Bununla birlikte, evlilik sözleşme niteliğinde kabul edilse de bir borçlar hukuku sözleşmesi gibi vasıflandırılamaz. Farklı yaş, cinsiyet ve kültürlere mensup insanların uzun dönemli beklentilerinin karşılanması gerekmektedir. $\mathrm{Bu}$ farklılıklar aynı zamanda aile hukukunu sözleşmeselleştirmenin gerekçeleri olarak da ileri sürülebilir. Evliliğin duygusal ve sosyal yönü ağır basan bir hukuki ilişki türü olması da onun diğer sözleşmeler gibi kabul edilmesine imkân vermez. $\mathrm{Bu}$ 
yönüyle doktrinde doğru bir şekilde ifade edildiği üzere modern evlilik statü meselesi olarak nitelenemeyeceği gibi sadece bir sözleşmesel ilişki olarak da nitelenemez. Daha ziyade karma nitelikli uzun dönemli ilişkisel bir sözleşme olarak nitelenebilir. Bu tür sözleşmeler tarafların bireysel özelliklerine göre düzenlenen ama ileride zaman ve değişen ihtiyaçlara bağlı olarak uyarlama mekanizmaları içeren ve böylece evliliği uzun dönemli ve istikrarlı bir kurum haline getiren nitelikte olmalıdır. (Shakargy, 2013: 528)

Batı hukuklarında statüden sözleşmeye doğru bir evrim olmakla beraber belirtmek gerekir ki doktrinde aile hukukunda irade serbestîsi aleyhine görüşler de ileri sürülmektedir. Bu eleştirilerden birincisi farklı çıkarlara sahip taraflar arasında pazarlık gücünün eşit olmasının önemli olduğu ve ailede taraflar arasındaki çok yakın ilişkilerin bulunmasının pazarlık güçlerini bozabileceğidir. İkincisi aile ilişkilerinin dinamikliği ve değişkenliği sonucu önceden yapılmış bir sözleşmenin ileride kişisel çıkarlar söz konusu olduğunda adil olmayan sonuçlar doğurabileceğidir. Üçüncüsü ise ailenin devletin dahi sağlayamadığ sosyal güvenlik fonksiyonları sağladığı ve ekonomik temelli anlaşmaların bu fonksiyonu bozabileceğidir. (Swennen, 2013)

\section{Aile Hukuku Alanında, Boşanmada, Kanunlar İhtilafı Kurallarının Evrimi}

Modern milletlerarası özel hukuk anlayışı, özellikle Kıta Avrupası hukuk sistemlerinde temellerini 19. yüzyılda faaliyet göstermiş, sırasıyla Savigny ve Mancini isimli iki hukukçunun doktrinlerinde bulmaktadır. Bu hukukçulardan önce asırlar boyunca statüler teorisi uygulanacak hukukun tespitinde kullanılmaktaydı. Statüler teorisi maddi hukuk kurallarından hareket etmekte ve örneğin, şahsın hukukuna ilişkin maddi hukuk kurallarının kişiyi her nerede olursa olsun takip edeceği kabulünden hareket etmekteydi. Şahsa ilişkin ikametgâhının bulunduğu yer hukuk kurallarının uygulanması esasını kabul etmekteydi. (Nomer, 2017: 52-53)

Savigny statücülerin hukuk kurallarından hareket eden anlayışı yerine hukuki ilişkileri esas alan anlayışı getirmiştir. Savigny yaklaşımına göre her hukuki ilişkinin niteliği itibariyle ait bulunduğu hukuk alanı, oturma yeri (sitzseat) tespit edilmelidir. Her hukuki ilişkinin ait olduğu yere göre en uygun hukuk sisteminin uygulanması hedeflenmektedir. O hukuki ilişkinin oturma yeri neredeyse iç hukuk veya yabancı hukuk fark etmeden uygulanacaktır. $\mathrm{Bu}$ çerçevede, şahsi statü için ikametgâh hukukunu oturma yeri, merkez olarak kabul etmiştir. (Çelikel, Erdem, 2017: 51-52; Nomer, 2017: 55-56)

Mancini doktrininde ise esas olan unsur kişinin milli hukukuna tabi olmasıdır. Mancini, milletlerin ve onların hukuklarının coğrafyalarının, ikliminin, örf-adet ve kültürünün özelliklerini taşıdığını ve kişilere milli hukuklarının uygulanması gerektiğini ileri sürmüştür. Mancini, şahsi 
menfaatlere hizmet eden kuralların bir ülkenin vatandaşlarına uygulanması gerektiğini, yabancılara da bulundukları ülkelerde kendi milli hukuklarının uygulanması gerektiğini ileri sürmüştür. Bu yaklaşımın en önemli etkisi, Kıta Avrupası hukuk sisteminde ikametgâh yerine vatandaşlık bağlama noktasına geçilmesidir. $\mathrm{Bu}$ anlayış 20. yüzyılın ikinci yarısına kadar devletlerin kodifikasyonlarında ve Lahey konferanslarında etkili olmuştur. (Çelikel, Erdem, 2017: 52-53; Nomer, 2017: 56-57)

20. yüzyılın ikinci yarısından itibaren hukuki ilişki ile en sıkı bağlantı kavramı esas alınmaya başlanmıştır. Objektif bağlanmada hukuki ilişkiyle en s1kı ilişkili hukukun uygulanması gerektiği benimsenmiştir. (Nomer, 2017: 66) Hukuki uyuşmazlık ve tarafları ile en sıkı ilişkiye sahip hukukun uygulanması kanunlar ihtilafı kurallarının temel amacı olan milletlerarası özel hukuk hakkaniyetinin gerçekleştirilmesini sağlamaktadır. Milletlerarası özel hukuk hakkaniyetini gerçekleştirirken hukuki ilişkide esas olan menfaatler tespit edilmektedir. $\mathrm{Bu}$ çerçevede taraf menfaatinin esas olduğu uyuşmazlıklardan başlıcaları aile ve şahsın hukukuna ait uyuşmazlıklardır. (Şanlı, Esen, Figanmeşe, 2018: 25-27) Taraf menfaatinin esas olduğu şahsi statünün bağlama noktaları milli hukuk, ikametgah ve 20 . yüzyılın ikinci yarısında ortaya çıkan mutad mesken bağlama noktalarıdır. Bu bağlama noktalarının esas alınmasının sebebi kişinin içinde yaşadığ 1 , bildiği varsayılan ve ona göre hareket ettiği hukukun uygulanmasının yerinde olmasıdır. (Tekinalp, Çavuşoğlu, 2011: 31; Doğan, 2019: 205; Aybay, Dardağan, 2008: 36-37)

Mutad mesken, sosyal hareketliliğin artması ve eşlerin aynı milliyet veya ikametgaha sahip olamayabileceği yaşam tarzları neticesinde, kişinin en yakın irtibatlı olduğu hukukun yaşadığı yer hukuku olduğu gerekçesine dayanarak ortaya çıkmıştır. (Shakargy, 2013: 522; Çelikel, Erdem, 2017: 63-64) Aile hukuku ilişkilerinde ve boşanmada taraf menfaatinin esas alınması nedeniyle tercih edilen milli hukuk, ikametgah veya mutad mesken hukuklarının uygulanmasında da taraflardan birine ait olan bağlama noktalarından ziyade eşitliğin gözetilmesinin ve evliliğin ortak hayata dair bir ilişki olmasının neticesi müşterek milli hukuk, müşterek ikametgah veya müşterek mutad mesken bağlama noktalarının kullanılmasının uygun olduğu belirtilmiştir. (Tekinalp, Çavuşoğlu, 2011: 207-208; Doğan, 2019: 341)

20. yüzyılın ikinci yarısından itibaren görülen bir diğer önemli gelişme temel insan hakları anlayışının gelişmesine paralel olarak irade serbestîsi ilkesinin kanunlar ihtilafı hukukunda alanının genişlemesidir. Kişinin, kişiliğini geliştirme serbestîsinin korunması temel insan haklarına dâhil edilmiştir. $\mathrm{Bu}$ doğrultuda, sözleşmeler hukukunun yanı sıra aile, miras, haksız fiil alanlarında da sınırlı da olsa irade serbestîsi uygulanmaya başlanmıştır. İrade serbestîsi ilkesinden hareketle bir hukuki ilişkinin oluşumunda ve içeriğini 
kararlaştırmada serbesti sahibi olan kişinin onu belirli bir hukuk sistemine tabi tutmada da iradeye sahip olduğu kabul edilmektedir. (Nomer, 2017: 66)

\section{Roma III Tüzüğü ve Hukuk Seçimi}

\section{Tarihi Gelişim ve Uygulama Alanı}

Roma III Tüzüğü öncesi $\mathrm{AB}$ üyesi devletlerde boşanmaya uygulanacak hukuk konusundaki kanunlar ihtilafi kurallarında esaslı farklılıklar bulunmaktaydı. AB üyesi devletlerde değişik sıralamalarla müşterek milli hukuk, son müşterek milli hukuk, müşterek milli hukuk bulunmuyorsa müşterek mutad mesken hukuku, son müşterek mutad mesken hukuku gibi irtibat noktaları kullanan basamaklı kuralların yanı sıra, son müşterek ikametgâh hukuku veya forum hukuku gibi irtibat noktalarının kullanılması yoluyla uygulanacak hukukun tespitini sağlayan çeşitlilikte kanunlar ihtilafı kuralları mevcuttu. Almanya, Belçika, Hollanda, İspanya gibi ülkelerde ise son derece sınırlı hukuk seçimi imkânı bulunmaktaydı. (Özçelik, 2012: 514-515; Tütüncübaş1, 2016: 430) Kanunlar ihtilafı kurallarındaki bu farklılıkların yanı sıra üye devletlerde aile değerleri noktasındaki yaklaşım farklılıkları yukarıda da ele aldığımız üzere boşanmaya dair maddi hukuk düzenlemelerinde de esaslı farklılıkların bulunmasına sebep olmuştur. Kuzey ülkeleri gibi bazı ülkelerde kusura dayalı boşanma anlayışı terk edilmiş ve boşanmak için taraflardan birinin talebi yeterli görülmekteyken, İrlanda, İtalya, Polonya, Slovakya gibi boşanmaya son derece sınırlı hallerde izin veren ülkeler de mevcuttur. İsveç gibi ülkeler boşanma konusunda kendisinden daha sıkı düzenleme getiren ülke hukukunu uygulamayı reddetmektedir. (Aybay, Dardağan, 2008: 212; Özçelik, 2012: 514-517; Tütüncübaş1, 2016: 430)

$\mathrm{AB}$ üyesi devletler arasındaki gerek boşanmaya ilişkin yukarıda ele aldığımız maddi hukuk farklılıkları gerekse kanunlar ihtilafı kuralları farklılıkları tarafların uyuşmazlığa hangi hukukun uygulanacağını öngörememelerine sebep olmakta ve hukuki kesinliği ve öngörülebilirliği engellemekteydi. (Özçelik, 2012: 514-515) Maddi hukuklarda ve kanunlar ihtilafı kurallarındaki bu farklılıkların yol açtığı önemli problemlerden biri de yabancı unsurlu boşanma davalarında üye devlet mahkemelerinin yetkisini düzenleyen Brüksel IIa Tüzüğü'nün 3. maddesinde yer alan yedi alternatifli yetki kuralının sağladığı imkanlar ve yabancı derdestlikle ilgili m. 19.1 neticesi davanın ilk açıldığı mahkemeye öncelik tanınması nedeniyle eşlerden birinin kendi lehine olan hukukun uygulanmasını sağlayan mahkemeye başvurmasıydı. (Tütüncübaş1, 2016: 431)

$\mathrm{Bu}$ çerçevede, boşanma ve ayrılığa uygulanacak hukuku tespit eden kanunlar ihtilafı kurallarını uyumlulaştırmak üzere, 20 Aralık 2010 tarihinde "Boşanma ve Ayrılığa Uygulanacak Hukuk Alanında Güçlendirilmiş İşbirliğinin Uygulanmasına Dair Konsey Tüzüğü” kabul edilmiştir. Roma III 
Tüzüğü olarak da adlandırılan bu düzenlemeye toplam 14 AB üyesi devlet katılmıştır ${ }^{1}$. Roma III Tüzüğü'nün Dibacesi'nin 1. paragrafinda AB'nin temel amaçlarından birisinin Birlik bünyesinde kişilerin serbest dolaşımının sağlanması olduğu belirtilmiştir. Bu amacı gerçekleştirmenin araçlarından birisinin de uluslararası nitelikli özel hukuk ilişkilerinde adli işbirliğini sağlamanın yollarından birisi olan kanunlar ihtilafi kurallarının uyumlulaştırılması olduğu belirtilmiştir. Dibace'nin 9. paragrafinda belirtildiği üzere Roma III Tüzüğü, boşanma ve ayrılığa uygulanacak hukuk konusunda üye ülkelerde aynı kanunlar ihtilafı kurallarının uygulanması yoluyla hukuki kesinliği ve öngörülebilirliği sağlamayı amaçlamaktadır. Yeknesak kuralların uygulanması taraflardan birinin kendisi için daha avantajlı hukukun uygulanmasını sağlayan bir mahkemeye başvurması yoluyla forum shoppingi de engelleyecektir.

Tüzük, uygulama alanını belirleyen m.1/1'de belirtildiği üzere boşanma ve ayrılıkta kanunlar ihtilafı içeren durumlarda uygulanacaktır. Dibace'nin kapsamla ilgili 10. paragrafinda Tüzük'te yer alan kanunlar ihtilafı kuralları tarafından belirlenen hukukun boşanma ve ayrılık sebeplerine uygulanacağ belirtilmiştir. Boşanma ve ayrılık sebepleri bakımından aynı kanunlar ihtilafı kurallarının geçerli olmasının sebebi birçok hukukta ayrılığın boşanmanın ön şartı kabul edilmesi ve ayrılık kurumunu kabul eden ülke hukuklarında her ikisine de aynı kanunlar ihtilafı kurallarının uygulanmasıdır. (Özçelik, 2012: 519)

Roma III Tüzüğü'nün kapsamı dışında bıraktığı konular ise m. 1/2'de belirtilmiştir. Tüzük, boşanma ve ayrılık davalarında sadece ön mesele olarak ortaya çıksa dahi, ehliyete, evliliğin varlığı, geçerliliği ve tanınmasına, evliliğin iptaline, isme, evliliğin malvarlığı alanındaki sonuçlarına, velayete, nafakaya uygulanmayacaktır. Dibace'nin 10. paragrafinda da aynı konular sayıldıktan sonra bu konulara üye devletlerde yürürlükte olan kanunlar ihtilafı kurallarının uygulanacağı belirtilmiştir. Tüzük'te yer alan düzenlemelerden boşanmaya ve ayrılığa uygulanacak hukukun kapsamının boşanma ve ayrılık sebepleri ve şartları ile sınırlı olduğu, boşanmanın sonuçlarının kapsam dışı bırakıldığı görülmektedir. Bu konuların kapsam dışı bırakılmasının sebebi nafaka, velayet gibi konular bakımından üye devletlerin birçoğunun uluslararası antlaşmalara taraf olmasıdır. Ayrıca, madde metninde belirtilen konuların tamamı için üye devletlerin uzlaşmasını sağlamak son derece zordur. (Özçelik, 2012: 519)

Roma III Tüzüğü, m. 4 ve Dibace paragraf 12'de belirtildiği üzere evrensel uygulamaya sahiptir. Tüzük uyarınca uygulanacak hukukun Tüzük'ü kabul etmiş bir üye devlet hukuku olup olmadığına veya üye olmayan devlet hukuku

${ }^{1} \mathrm{Bu}$ ülkeler şunlardır: Almanya, Avusturya, Belçika, Bulgaristan, Fransa, Macaristan, İtalya, Letonya, Lüksemburg, Malta, Portekiz, Romanya, Slovenya ve İspanya. 
olup olmadığına bakılmaksızın uygulanacaktır. Evrensellik ilkesi neticesi objektif kural gereğince veya tarafların seçimi ile AB Temel Haklar Şartı veya $\mathrm{AB}$ kurucu antlaşmalarında yer alan insan haklarına aykırı bir düzenleme getiren veya boşanmayı tanımayan bir hukuk sistemi seçildiğinde kamu düzeni müdahalesi gerçekleşecektir. (Carruthers, 2012: 890)

Roma III Tüzüğü açısından dikkat çekici bir başka husus m. 11 düzenlemesi uyarınca atfın reddedilmiş olmasıdır. Tarafların $\mathrm{m}$. 5 uyarınca hukuk seçimi yaptıkları durumlarda atfın reddedilmesi doğaldır. Roma III Tüzüğü m. 8 uyarınca objektif kuralın uygulandığı hallerde de atfın reddedilmiş olması MÖHUK m. 2/3 uyarınca kişiler ve aile hukuku meselelerinde atfı kabul eden Türk hukukundan farklılık göstermektedir.

\section{Hukuk Seçiminin Genel Esasları}

Roma III Tüzüğü’nün 5. maddesinde, aynı zamanda Tüzük'ün getirdiği en önemli yenilik olan, hukuk seçimine imkân verilmiştir. Taraflar m. 5.1'de belirtilen dört hukuk sisteminden birisini seçebileceklerdir. Bu hukuklardan birincisi hukuk seçimi anlaşmasının yapıldığ hukukudur. İkincisi, anlaşmanın yapıldığ 1 sirada eşlerden birisinin mutad meskeni hala orada bulunmak koşuluyla eşlerin son mutad meskeni hukukudur. Üçüncüsü, eşlerden birinin anlaşmanın yapıldığı sıradaki vatandaşlığ hukukudur. Dördüncüsü ise forum hukukudur.

Roma III Tüzüğü'nün 8. maddesinde hukuk seçimi olmadığı hallerde uygulanacak basamaklı nitelikteki objektif bağlama kuralına yer verilmiştir. $\mathrm{Bu}$ kurala göre öncelikli olarak dava açıldığı tarihteki eşlerin mutad meskeni hukuku uygulanacaktır. Bu hukukun bulunmaması halinde ikinci basamakta, eşlerden birisi hala son mutad meskenin bulunduğu ülkede oturuyor olmak kaydiyla ve üzerinden bir yıldan fazla zaman geçmemiş olmak kaydıyla eşlerin son mutad meskeni hukuku uygulanacaktır. Bu şartların sağlanamaması durumunda üçüncü basamakta, eşlerin müşterek milli hukuku uygulanacaktır. Bunun da bulunmaması halinde dördüncü basamakta forum hukukunun uygulanacağına yer verilmiştir. Objektif kural bu şekilde olmakla beraber bizim makalemizin konusunu m. 5 'te yer alan hukuk seçimi oluşturmaktadır.

Aile hukuku ilişkilerinin self determinasyon temelinde bireylerce düzenlenmesi batı hukuk sistemlerinde görülen en önemli gelişmelerden biridir. Avrupa İnsan Hakları Sözleşmesi m. 8'de yer alan özel hayata ve aile hayatına saygı bireylerin hayatlarını ilgilendiren temel kararları alma hakkına saygıyı da içermektedir. Aile hukukunun bireysel boyutunun gittikçe önem kazanması ve maddi hukuk alanında bireylere tanınan irade serbestîsi aile hukukuna ilişkin kanunlar ihtilafı hukukuna da yansımıştır. Bu gelişmenin en belirgin sonucu Roma III düzenlemesinde yer aldığı gibi eşlerin boşanma ve ayrılığa uygulanacak hukuku seçebilmeleridir. (Franzina, 2011: 108-109) Avrupa 
Adalet Divanı ve Avrupa İnsan Hakları Mahkemesi'nin aile ve özel hayata saygıyı devletlerin aile hukuku alanında da irade serbestîsine uyması gerektiği şeklinde yorumlaması da bireylere uygulanacak hukuku seçme imkânının verilmesindeki sebeplerden birisidir. (Yetano, 2010: 156) AB'ye üye ülke vatandaşlarının sosyal hareketliliğinin artması hukuki kesinliğin ve esnekliğin de sağlanmasını gerektirmektedir. Bu amacın gerçekleşmesi için Tüzük sınırlı hukuk seçimi imkânını getirmiştir ${ }^{2}$. Milletlerarası özel hukukta irade serbestîsinin en temel faydalarından birisi hukuki güvenliği sağlayacak olmasıdır. Tarafların seçtikleri hukukun uygulanması öngörülebilirliği ve tarafların beklentisinin gerçekleşmesini sağlayacaktır. Bu ilke boşanma davaları için de elbette geçerlidir. (Kruger, 2014; Franzina, 2011: 109) Hukuk seçimi imkânının tanınması, AB üyesi ülkelerde nafaka, mal rejimleri gibi çeşitli aile hukuku ilişkilerine farklı tüzüklerin, kanunlar ihtilafı kurallarının uygulanması nedeniyle ortaya çıkabilecek sorunları gidermek noktasında taraflara bu ilişkileri aynı hukuka tabi tutmak imkânını sağlamaktadır. Sağlanan bu fayda da hukuki güvenliği artırıcı niteliktedir. (Franzina, 2011: 110)

İrade serbestîsi doğrultusunda hukuk seçimi imkânı tanınmasına rağmen kanunlar ihtilafi alanındaki temel prensip değişmemiştir. Hukuk seçimi birden fazla ülke hukukunun uygulanabilmesi ihtimalini ve imkânını sağlasa da zayıf veya güçlü bağlarla kişiyle irtibatlı bir devlet hukuku seçilebilmektedir. (Shakargy, 2013: 522-523) İrade serbestîsi yolu ile devlet hukuku niteliğinde olmayan dini kuralların vb. seçilmesi mümkün değildir. (Carruthers, 2012: 890) Kanunlar ihtilafı kurallarının kaynağını egemen güçler olan ulus devletlerin veya $\mathrm{AB}$ gibi devletler tarafından kurulmuş ulus-üstü birliklerin oluşturması nedeniyle, irade serbestisi de bu devlet veya devlet üstü kurumların tanıdığ ölçüde kullanılabilecektir. (Carruthers, 2012: 885)

Yukarıda belirttiğimiz üzere, Brüksel IIa Tüzügü’nde yer alan geniş yetki kuralları, yabancı derdestliğin kabulüne imkân veren düzenleme ve tanıma tenfiz aşamasında yetki temelli bir kontrolün olmaması tarafların kendilerine uygun hukukun uygulanmasını sağlayan ülke mahkemesinde dava açması yoluyla dolaylı hukuk seçimine neden olmaktaydı. Kanunlar ihtilafı kurallarının uyumlulaştırılması ve hukuk seçimi imkânının tanınması bu durumu engelleyici ve düzenleyici niteliktedir. (Fiorini, 2008: 190) Hukuk seçimi ayrıca Tüzük'ün temel ön kabulleri olan boşanma hakkının olması ve boşanmanın eşitlikçi, kolay ve hızlı olmasını da gerçekleştirmektedir. (Fiorini, 2008: 193-194) Hukuk seçimi imkânının tanınması ile Tüzük'teki objektif kural olan m. 8'de yer alan ve bazı kabullere dayanan, her zaman eşlerin en sıkı ilişkide oldukları hukukun uygulanmasını sağlayamayan düzenlemelerin sakıncalarını gidermek amaçlanmıştır. (Tütüncübaşı, 2016: 441) 
Seçilen hukuk tarafların mutad mesken veya vatandaşlık temelli ya özel bir bağlantıya sahip olduğu hukuk ya da forum hukuku olmak zorundadır. Ayrıca, seçilen hukukun AB Temel İnsan Hakları Şartı ve AB Antlaşmaları'nda yer alan temel haklar ile uyumlu olması gerekmektedir ${ }^{3}$. Tüzük, Avrupa Temel İnsan Hakları Şartı'nda yer alan temel insan haklarına ve özellikle cinsiyet, 1rk, renk, etnik veya sosyal kökene, dil, din, inanç ve belli bir azınlığa mensup olmaya dayalı ayrımcılık yasağını öngören m. 21'e riayet edilerek uygulanacaktır ${ }^{4}$. Bu düzenlemelere uygun olmayan hukuk sistemi seçilse dahi Tüzük m. 12 uyarınca kamu düzeni müdahalesine uğrayacaktır.

Hukuk seçiminde temel alınması gereken bir diğer esas ise seçimin bilinçli olması gerektiğidir. Tarafların seçimlerinin sosyal ve hukuki etkileri konusunda bilgili olmaları gerekir. Hukuk seçiminin taraflarca eşitlik temelinde ve birlikte yapılması gerekmektedir ${ }^{5}$. Bilinçli hukuk seçimini sağlamak üzere tarafların ulusal hukukların ve Birlik hukukunun önemli yönlerine erişimlerinin mümkün kılınması gerektiği belirtilmiştir. Bunun için internet tabanlı bilgilendirme sisteminin Birlik tarafından düzenli yenilendiği belirtilmiştir ${ }^{6}$. Seçimin bilinçli bir şekilde ve birlikte yapılması taraflardan birinin kendi avantajına olan hukukun uygulanmasını sağlamayı amaçlayan tek taraflı bir otonomiye sahip olmasinı engellemektedir. (Harding, 2011: 225)

Tüzük'ün hukuk seçimini düzenleyen 5. maddesinin 2. ve 3. fikralarında hukuk seçiminin ne zaman yapılacağı düzenlenmiştir. Buna göre, hukuk seçimi anlaşması en geç dava açıldığı sırada olmak koşuluyla evliliğin başlangıcından itibaren her an yapılabilir ve değiştirilebilir. Bununla birlikte, en geç dava açıldığı sırada yapılabilmesine bir istisna getirilmiştir. Forum hukukunun izin vermesi kaydıyla, eşler dava sürecinde de hukuk seçimi yapabilecektir. Dava sürecinde hukuk seçimi yapılması halinde bu seçim forum hukukuna uygun olarak kayıt altına alınacaktır.

\section{Hukuk Seçimi Anlaşmasının Geçerlilik Koşulları}

Hukuk seçimi anlaşmasının maddi geçerliliği Roma III Tüzüğü’nün 6 . maddesinde düzenlenmiştir. Roma III Tüzüğü m. 6.1 uyarınca hukuk seçimi anlaşmasının varlığı ve geçerliliğine eğer anlaşma geçerli olsaydı hangi hukuk uygulanacaksa o hukuk uygulanacaktır. Seçilen hukuk, hukuk seçimi anlaşmasının geçerliliğine de uygulanacaktır. Bununla birlikte, m. 6.2 uyarınca hukuk seçimi yönünde iradesi olmadığını iddia eden eşin iddiasının seçilen

\footnotetext{
${ }^{3}$ Dibace, par. 16.

${ }^{4}$ Dibace, par. 30.

${ }^{5}$ Dibace, par. 18.

${ }^{6}$ Dibace, par. 17.
} 
hukuka göre tespitinin makul olmadığı şartlardan anlaşılırsa, dava açıldığ sırada mutad meskeninin bulunduğu ülke hukukuna göre değerlendirilmesi mümkündür.

Hukuk seçimi anlaşmasının şekli geçerliliği, uyulması gereken şekil kuralları ise Roma III Tüzüğü'nün 7. maddesinde düzenlenmiştir. Buna göre, hukuk seçimi anlaşması yazılı olmalı, tarihi belirtilmeli ve eşlerden her ikisi tarafından imzalanmalıdır. Anlaşmanın kayıt altına alınmasını sağlayan herhangi bir elektronik araçla yapılan anlaşma da yazılılık şartını sağlamaktadır. Bununla birlikte, anlaşmanın yapıldığ 1 sırada eşlerin her ikisinin de mutad meskeninin bulunduğu taraf ülke hukuku ilave şekil koşulları getiriyorsa bu şartların da sağlanması gerekir. Eşlerin anlaşmanın yapıldığı sırada farklı taraf ülkelerde mutad meskenlerinin bulunması ve bu ülke hukuklarının farklı şekil kurallarına sahip olması halinde bu iki hukuktan birinin şekil şartlarını sağlayan anlaşma da geçerlidir. Eşlerden sadece birisinin mutad meskeninin taraf üye ülkede olması halinde o ülke hukukunun ilave şekil şartlarının sağlanması gerekmektedir. Tüzükle getirilen kuralların ulusal hukuklardaki ilave şartlarla desteklenmesi sonucunda geçerliliğe uygulanacak hukuk, tarafların mutad meskeni gibi unsurlara göre değişeceğinden yeknesaklaştırma amacına aykırı olduğu ileri sürülmüştür. (Franzina, 2011: 115) Roma III Tüzüğü'nün Dibacesi'nin 19. paragrafinda belirtildiği üzere maddi ve şekli geçerlilik şartlarının ayrıntılı düzenlenmesinin sebebi bilinçli hukuk seçiminin ve hukuki kesinliğin sağlanmasıdır. Özellikle şekil şartları tarafların hukuk seçiminin sonuçlarının bilincinde olması, bilinçli hukuk seçimi için önemlidir. Dibacede taraf ülke hukuklarında yer alabilecek ilave şartlara örnek olarak hukuk seçimi anlaşmasının evlilik sözleşmesinde yer alması ve o ülke hukukunun buna ilişkin özel şekil şartları düzenlemesi örnek verilmiştir.

Roma III Tüzügü̈nün şekli geçerlilik şartlarını düzenleyen m. 7.1'de tarafların iradelerini aynı anda veya şahsen beyan etmelerinin talep edilmemesi nedeniyle, devam eden fikralardaki ulusal hukuklarda daha sıkı koşullar öngörülmediği sürece, eşler temsilci vasıtasıyla da hukuk seçimi yapabileceklerdir. Hukuk seçiminin yazılı şekil şartı getirmesi nedeniyle seçim açık olmak zorundadır. Zımni hukuk seçimi kabul edilmemiştir. (Tütüncübaşı, 2016: 445) Roma III Tüzügü’nün 7. maddesinde belirtildiği üzere maddede yer alan şekil şartları 5. maddenin 1. ve 2. fikraları uyarınca yapılan hukuk seçimi anlaşmaları için geçerlidir. Hukuk seçiminin 5. maddenin 3. fikrası uyarınca dava sürecinde yapılması durumunda m. 7.1'de yer alan şekil kuralları yerine davanın görüldüğ̈̈ mahkemenin şekil kurallarına göre kayıt altına alınması gerekecektir. (Tütüncübaş1, 2016: 446) 


\section{Roma III Tüzüğ̈̈ Uyarınca Seçilebilecek Hukuklar}

Roma III Tüzüğ̈̈'nün 5. maddesi uyarınca taraflar 1. fikrada belirtilen dört hukuk sisteminden birisini seçebileceklerdir. Bu hukuklardan birincisi, hukuk seçimi anlaşmasının yapıldığı sırada tarafların mutad meskeni hukukudur. İkincisi, anlaşmanın yapıldığı sırada eşlerden birisinin mutad meskeni hala orada bulunmak koşuluyla eşlerin son mutad meskeni hukukudur. Üçüncüsü, eşlerden birinin anlaşmanın yapıldığı sıradaki vatandaşlığı hukukudur. Dördüncüsü, forum hukukudur. Seçilebilecek hukuklara bakıldığında mutad mesken veya milliyete dayalı hukuklarda olduğu gibi eşle bağlantılı bir hukuk seçilebilmektedir. Diğer alternatif ise davanın görüldüğü mahkeme hukukudur. Hukuk seçimini düzenleyen 5. maddede kullanılan bağlama noktaları ile objektif kuralı düzenleyen basamaklı nitelikteki 8. maddede yer alan bağlama noktalarının aynı olduğu görülmektedir. Farklılık, objektif kuralda mutad mesken bağlama noktasının kullanılmasında dava tarihi esas alınırken hukuk seçiminde anlaşmanın yapıldığı sıradaki mutad meskenin esas alınması ve objektif kuralda ortak milli hukuk uygulanabilirken hukuk seçiminde ortak milli hukuk olmasa dahi eşlerden birisinin milli hukukunun seçilebilmesidir.

\section{Mutad Mesken Hukuku}

Roma III Tüzüğü uyarınca eşler hukuk seçimi anlaşmasını yaptıkları sıradaki ortak mutad mesken hukukunu seçebilirler. Hukuk seçimi anlaşması sırasında ortak mutad meskene sahip değillerse, eşlerden birisinin mutad meskeninin hala orada bulunması koşuluyla, son ortak mutad mesken hukukunu da seçebilirler.

Mutad mesken hukuki bir kavram olmaktan ziyade olgulara dayalı gerçek ve fiili bir durumun ifadesidir. İkametgâh kavramının aksine kanunlarda veya diğer hukuki metinlerde tanımlanmamış ve unsurları belirtilmemiştir. Bununla birlikte, mutad meskenin oluşumu için iki unsur gerekmektedir. Bunlardan birincisi, oturmanın devamlılığıdır. Oturmanın devamlılığı için fiilen orada oturma ve o yeri hayat ilişkilerinin merkezi haline getirecek kadar bir süre, devamlılık gerekmektedir. İkinci unsur, oturma niyetidir. Oturma niyetinin tespiti için kişi ile o yer arasında sosyal bütünleşmenin gerçekleşmesi, o yeri benimsemesi, kişinin orada yaşama isteğinin olması gerekir. Oturma niyeti özellikle oturma süresinin kısa olması halinde o yerin kişinin mutad meskeni haline gelip gelmediğinin tespiti açısından önem taşır. (Arslan: 2014: 171-172) Genel kabul, mutad meskenin kişinin hayatının ağırlık merkezinin bulunduğu yer olduğu şeklindedir. O yerin kişinin hayatının ağırlık merkezini teşkil edip etmediği her bir davada bütün koşullar değerlendirilerek karara bağlanacaktır. (Fawcett, Carruthers, 2008: 185) Kişinin işi, aile ve dost çevresi itibari ile bir yerle sosyal bütünleşmesinin gerçekleşmesi o yeri kişinin hayatının ağırlık merkezi haline getirir ve o yer kişinin mutad meskeni olur. (Nomer, 2017: 121) 
Mutad meskenin hukuki bir kavramdan ziyade fiili bir durumu yansitması onun geliştirilme ve tercih sebeplerinden biridir. Hukuki bir kavram olan ikametgâhın farklı hukuk sistemlerinde farklı anlamlar içermesi ve bunun doğurduğu vasıflandırma farklılıkları mutad meskenin tercih edilmesine yol açmıştır. Ayrıca ikametgâh gerçek fiili durumu yansıtmayabilmektedir. Mutad meskenin bir diğer ortaya çıkma sebebi ise özellikle Lahey sözleşmelerinin hazırlanması sirasında Kıta Avrupası hukuk sisteminde kullanılan bağlama noktası olan milli hukuk ile Anglo-sakson hukuk sisteminde kullanılan bağlama noktası olan ikametgâh hukukunu uzlaştırma çabasıdır. (Şanlı, Esen, Figanmeşe, 2018: 35-36) Ayrıca, kişinin fiilen yaşadığı yerle bağlantısı daha yoğun olacağı için taraf menfaatine daha fazla hizmet etmektedir. (Doğan, 2019: 211)

Mutad meskenin vatandaşlığa nazaran tercih edilmesinin bir diğer sebebi kavramın esnekliği ve sosyal mobilitenin artmasıdır. Kişinin zamanla vatandaşı olduğu ülke ile bağının azaldığı ve yaşadığı ülke kurallarına göre boşanması gerektiği anlayışına dayanmaktadır. Bununla birlikte, gayet kısa sürede edinilebilen mutad meskenin kişisel statüde en sık1 ilişkili hukukun uygulanmasını sağlayamayacağı gerekçesiyle eleştirilmiştir. (Gaertner, 2006: 132-133) Mutad meskene getirilen bir diğer eleştiri ise olgulara dayalı ve tanımdan uzak niteliğinin hukuki kesinliği ve belirliliği zedeleyebileceğidir. (Carruthers, 2012: 890)

\section{Milli Hukuk}

Roma III Tüzüğü m. 5.1 uyarınca seçilebilecek hukuklardan birisi de eşlerden birinin milli hukukudur. Bu şekilde, eşlerin ortak milli hukuka sahip olmaması durumunda dahi milli hukuklardan birinin seçimine imkân verilmiştir. Vatandaşlık da ikamet gibi kişi ile devlet ve hukuk arasında bağlantı kurmak için kullanılan bir hukuki kavramdır. İkametgâha alternatif olarak vatandaşlık bağlama noktası 19. yüzyılda ulus devletlerin ortaya çıkması, bölgesel birimler yerine üniter yapıya geçilmesi ile olmuştur. (Shakargy, 2013: 503)

Evlenme ve boşanmaya dair kanunlar ihtilafı kuralları geleneksel olarak bir kişinin hukuki kimliğinin ana unsurunun belli bir devletle vatandaşlık veya ikamet temelinde oluşan bağı olduğunu kabul etmektedir. Bu bağın olduğu devlet o kişinin hukuki vatanı kabul edilmektedir. (Shakargy, 2013: 499-500) Kişilerin aile hukuku konularında, evlenme ve boşanmada, kültürel ve ahlaki değerler ağır bastığından, bu konuların kişilerin kültürel kimlikleri ve değer dünyası ile yakından ilgili olması nedeniyle en çok vatandaşı oldukları ülke ile ilişki içinde olduklarından hareketle milli hukukun uygulanması yoluna gidilmiştir. Milli hukukun uygulanmasının tarafların menfaatine ve kişilik haklarına uygun olacağı düşünülmektedir. (Şanlı, Esen, Figanmeşe, 2018: 29- 
30) Evlenmenin ve boşanmanın toplumun ahlak değerleri, nüfus ve ekonomik konulara dair etkilerini dikkate alarak devletler de milli hukuku tercih etme yoluna gitmişlerdir. (Shakargy, 2013: 500) Vatandaşlığın belirlenmesi hukuk sistemlerinde farklı anlamlar taşıyan ve vasıflandırma problemlerine yol açan ikametgâh kavramına göre ve sinırları net belli olmayan mutad mesken kavramına göre kolaydır. Devamlılık ve istikrar arz etmesi de bir diğer olumlu yönüdür. (Şanlı, Esen, Figanmeşe, 2018: 30)

Vatandaşlık prensibi ulus devletlerin ve milliyetçiliğin yükseldiği çağda devletlerarası farklılıklara herkesin kendi milli hukukunu uygulayarak sayg1 duymak temeline dayanıyordu. $\mathrm{AB}$ entegrasyonu farklılıkları vurgulamaktan ziyade yönetmeyi amaçlamaktadır. Vatandaşıı̆ıı bağlama noktası olarak kullanılması entegrasyonu engelleyebilir. Bununla birlikte AB'ni kuran antlaşmada da belirtildiği üzere $A B$ 'nin çeşitlilik içinde bütünlüğü sağlamayı hedefleyen bir yapı olduğu düşünüldügünde hala vatandaşlık bağlama noktasına dayanılabilir. (Gaertner, 2006: 116) Vatandaşlığın bağlama noktası olarak kullanılmasının temel sebebi milli hukukun kişinin kültürel aidiyetinin olduğu hukuk sistemi olmasıdır. $\mathrm{Bu}$ da ayrıca, hukukun kültürel kimliğin parçası olduğu ve kültürel kimliğin korunması gereken bir hak olduğu anlayışına dayanmaktadır. (Gaertner, 2006: 117) Kültürel kimlik hakkının vatandaşlık hukukunun uygulanmasını gerektirdiği söylenebilirse de vatandaşlık sadece tipik örneklerde bu aidiyeti sağlamaktadır. Bununla birlikte mutad meskene kişilerin daha fazla bağlantı içerisinde olduğu durumlarda bu gerekçelendirme geçerli değildir. (Gaertner, 2006: 123) Entegrasyon ve sosyal hareketliliğin özellikle sabit bir bağlama noktasının kullanılması yoluyla kişiyi belirli bir devlete bağlayarak onun hukuki ilişkilerine istikrar sağlanması gerektiği de ileri sürülmüştür. Özellikle sosyal hareketliliğin yüksek olduğu zamanlarda sıklıkla değişebilen mutad mesken yerine vatandaşlı̆ğn bir kişinin bir devlete kültürel aidiyeti açısından daha fazla bağlantı sağladığı söylenebilir. (Gaertner, 2006: 121)

\section{Lex Fori}

Boşanmaya uygulanacak hukuk açısından Anglo-sakson hukuklarında lex forinin gelişmesine gerekçe olarak boşanmanın kamu düzeni ve ahlaki değerler açısından sonuç doğurucu olması gösterilmiştir. Ayrıca yetki kuralları da lex fori olarak mahkeme hukukunun uygulanmasında etkin olmuştur. Temel yetki kuralının ikametgâh mahkemesi olması ve uygulanacak hukukun da ikametgâh hukuku olması mahkeme hukukunun uygulanması sonucunu doğurmuştur. $\mathrm{Bu}$ yaklaşım boşanmada temel çıkar olarak mahkeme devletinin yararının aranamayacağı gerekçesiyle bizatihi Anglo-sakson hukukçuları tarafından da eleştirilmiştir. (North, 1980: 82 vd.; Fawcett, Carruthers, 2008: 966) Ayrica, İngiliz hukukunda yabancı hukukun uygulanması tarafın talebine bağlı olduğundan dolayı tarafın bunu yapmaması durumunda forum hukuku lehine 
bilinçli veya bilinçsiz bir hukuk seçimi gerçekleşmektedir. (Carruthers, 2012: 885-886)

Boşanmaya milli değerler kapsamında lex forinin uygulanması, kamusal değerlerin dikkate alınması yabancı hukukun milli standartlara göre değerlendirilmesi olacağı ve maddi hukuk değerlerinin kanunlar ihtilafi aşamasına çıkarılmaması gerektiği için doğru değildir. Kanunlar ihtilafi kurallarının amacı maddi hukuk adaletini gerçekleştirmek değil en sıkı ilişkili hukukun uygulanmasını sağlamaktır. Bu nedenle, mahkeme ülkesinin milli, kültürel değerlerine aykırı olması yabancı hukukun uygulanmasını engellemez. Bu tür kaygılar kamu düzeni vb. önlemlerle giderilebilir. (Gaertner, 2006: 109110).

Bağlama noktasının tespitinde hukuki işlem ile ilgili yarışan menfaatler devreye girecektir. Hâkimin, mahkeme hukukunu uygulamasının basit olduğu, masrafı ve zaman israfinı engellediği ve bu durumun boşanmayı daha kolay sağlayacağ1 çoğu zaman doğrudur. Bununla birlikte bu gerekçeler ileri götürülürse kanunlar ihtilafı kurallarının temel ilkesi olan en sıkı ilişsili hukukun uygulanmasını ortadan kaldırabilir. (Gaertner, 2006: 113; Fiorini, 2008: 189) Tarafların boşanmayı en hizlı ve masrafsız şekilde elde edebilecekleri bir hukukun uygulanması ile en sıkı ilişkili hukukun uygulanması kanunlar ihtilafi kurallarınca dengelenmesi gereken iki çıkardır. Lex forinin seçilmesi imkânının tanınması ile bu iki çıkar dengelenmiştir.

\section{Sonuç}

Aile hukukunda batı hukuklarında gözlemlenen statüden sözleşmeye doğru evrim, kişilerin koşulları önceden belirlenmiş evlilik kurumunun bir parçası olmaktan öte, evlilik kurumu kapsamındaki maddi nitelikli olmayan hak ve yükümlülüklerini dahi kendilerinin belirlemelerine ve hatta evliliğin sona erme şartlarını belirlemelerine yol açmıştır. Öte yandan, bazı ülkelerde kusura dayalı olmayan boşanmanın ortaya çıkması ile doğal olarak taraflar boşanmayı daha kolay elde edebilecekleri hukuklara yönelmektedirler. İnsan hakları anlayışının gelişmesine paralel olarak kişisel kimlik hakkı, özel hayata ve aile hayatına saygının irade serbestîsinin de kabulünü gerektirdiği şeklindeki anlayış aile hukuku ilişkilerinde irade serbestîsinin yerleşmesine sebep olmuştur. Maddi hukuktaki bu gelişmelere paralel olarak, kanunlar ihtilafı hukuku alanında da kişilerin içeriğini ve sona erme sebeplerini belirleyebildikleri aile kurumuna hangi hukukun uygulanabileceğini de belirleyebilecekleri kabul edilmiştir. Boşanmada hukuk seçimine imkân tanıyan Roma III Tüzüğü bu gelişmenin ürünüdür. 
Roma III Tüzüğü ile hukuk seçimi imkânı sağlanmış olmakla birlikte bu imkân sınırlıdır. Taraflar ancak kendileriyle mutad mesken veya vatandaşlık temelinde belirli irtibatlara sahip hukukları ya da forum hukukunu seçebilirler. Hukuk seçimine ilişkin bir diğer sınırlama Roma III Tüzüğü'nün Avrupa İnsan Hakları Şartı'nda yer alan ayrımcılık yasağına uygun bir şekilde uygulanacak olmasıdır. Bu yasağa aykırı düzenlemeler içeren devlet hukuklarında yer alan kurallar kamu düzeni müdahalesine uğrayacaktır.

Hukuk seçimi imkânının tanınması diğer alanlarda olduğu gibi öngörülebilirliği ve hukuki güvenliği sağlayacaktır. Eşler birlikte ve seçtikleri hukukun etkilerinin farkında olarak, bilinçli bir şekilde, seçim yapmalıdırlar. $\mathrm{Bu}$ şekilde hukuk seçimi imkânının tanınması $A B$ üyesi ülke mahkemelerinde uygulanan geniş yetki kurallarından ve yabancı derdestliğin kabulünden kaynaklı eşlerden birinin önce dava açarak kendi lehine olan hukukun uygulanmasını sağlamasını engelleyecektir. Hukuk seçiminin sağladığı bir diğer fayda da aile hukuku alanında bağlama noktaları olarak kullanılan milli hukuk, mutad mesken hukuku, forum hukuku bağlama noktalarının teorik gerekçelendirmeleri bağlamındaki tartışmaları pratik açıdan etkisiz hale getirmiş olmasıdır. Taraflar, boşanmayı en kolay, hızlı ve masrafsız elde edebilecekleri hukuk sistemini seçebileceklerdir. 


\section{Kaynakça:}

Arslan, İ. (2014) Milletlerarası Özel Hukukta Mutad Mesken Kavramı, (İstanbul, On iki Levha)

Aybay, A. ve Dardağan, E. (2008) Uluslararası Düzeyde Yasaların Çatışması, 2. bs., (İstanbul, Bilgi Üniversitesi).

Carruthers, J. (2012) "Party Autonomy in the Legal Regulation of Adult Relationships: What Place for Party Choice in Private International Law", International and Comporative Law Quarterly, (61): 881-913.

Çelikel, A. ve Erdem, B. (2017) Milletlerarası Özel Hukuk, 15. bs., (İstanbul, Beta).

Doğan, V. (2019) Milletlerarası Özel Hukuk, 5. bs., (Ankara, Savaş).

Fawcett, J. Ve Carruthers, J. M. (2008) Cheshire, North \& Fawcett Private International Law, 14th ed., (Oxford, OUP).

Fiorini, A. (2008) "Choice of Law in Divorce: Is the Europeanization of Family Law Going Too Far", International Journal of Law Policy and the Family, (22): 178-205.

Franzina, P. (2011) "The Law Applicable to Divorce and Legal Separation Under Regulation (EU) No. 1259/2010 of 20 December 2010", Cuadernos de Derecho Transnacional, 3(2): 85-129.

Gaertner, V. (2006) "European Choice of Law Rules in Divorce (Rome III): An Examination of the Possible Connecting Factors in Divorce Matters against the Backgrounds of Private International Law Developments", Journal of Private International Law, (2): 99-136.

Harding, M. (2011) "The Harmonisation of Private International Law in Europe: Taking the Character out of Family Law", Journal of Private International Law, (7): 203-29.

Kapanc1, K. B. (2015) "Contractualisation of Family Law: Is it possible in Turkey?", R. Serozan, B. Başoğlu (ed.) Turkish Reports to the XIXth International Congress of Comparative Law, (İstanbul, Vedat) ss. 97-109.

Kruger, T. (2014) "Rome III and Parties' Choice", Familie and Recht, January 2014, DOI: $10.5553 / \mathrm{FenR} / .000013$.

Nomer, E. (2017) Devletler Hususi Hukuku, 22. bs., (İstanbul, Beta).

North, P. (1980) "The Development of Rules of Private International Law in the Field of Family Law", Collected Courses of the Hague Academy of International Law 1980, V. 166, ss. 9-117.

Özçelik, G. (2012) "Roma III Tüzüğü Uyarınca Boşanma ve Ayrılığa Uygulanacak Hukukun Tayini ve Uygulanmas1, $A \ddot{U} H F D, 61(2)$ : 505-39. 
Serozan, R., Başoğlu B., Kapancı K. B. (2016) “Aile Hukukunun Özellikleri, İlkeleri ve Gelişimi”, İKÜHFD, 15(2): 531-60.

Shakargy, S. (2013) "Marriage by the State or Married to the State? On Choice of Law in Marriage and Divorce", Journal of Private International Law, (9): 499-533.

Swennen, F. (2013) "Contractualisation of Family Law in Continental Europe" Family and Law, July-September 2013, DOI: 10.5533/FenR/000008.

Şanlı, C., Esen, E., Figanmeşe, İ. (2018) Milletlerarası Özel Hukuk, 6.bs., (İstanbul, Vedat).

Tekinalp, G., Çavuşoğlu A. (2011) Milletlerarası Özel Hukuk Bağlama Kurallarl, 11. bs., (İstanbul, Vedat).

Tütüncübaşı, U. (2016) "Boşanma ve Ayrılığa Uygulanacak Hukuk Hakkında Roma III Tüzüğü (AB 1259/2010) içinde I. Özkan, C. Süral, U. Tütüncübaş1 (ed.) Avrupa Birliği Devletler Özel Hukuku, (Ankara, Adalet) ss. 428-454.

Yetano, T. M. (2010) "The Constitutionalisation of Party Autonomy in European Family Law”, Journal of Private International Law, (6): 155-93. 